\title{
Transactions
}

\section{Tetrakis(diisopropyl amide) substituted norbornadiene and quadricyclane are highly barium selective ligands $\uparrow$}

\author{
Torsten Winkler, Monika Bayrhuber, Benjamin Sahlmann and Rainer Herges*
}

Received 2nd February 2012, Accepted 4th April 2012

DOI: $10.1039 / \mathrm{c} 2 \mathrm{dt30242j}$

Tetrakis(diisopropyl amide) substituted norbornadiene and quadricyclane derivatives were investigated for their extraction and transport capabilities with alkaline earth metal cations. Both amides exhibited a remarkably high preference of $\mathrm{Ba}^{2+}$ over any other alkali metal or alkaline earth cation. The binding geometries were determined by quantum chemical DFT calculations.

\section{Introduction}

The complexation and selective transport of alkaline earth metal cations in general and $\mathrm{Ba}^{2+}$ in particular have been thoroughly investigated for a long time. Important applications for $\mathrm{Ba}^{2+}$ extraction include the purification of spent nuclear fuel ${ }^{1}$ as well as sulfur analytics. ${ }^{2}$ Various binding domains have been successfully established, e.g. calixarenes, ${ }^{3-5}$ cyclic oligopeptides ${ }^{6}$ or substituted crown ethers. ${ }^{7}$ Especially the use of the lipophilic dicarbollyl-cobaltate anion in combination with a wide variety of donor ligands was extensively studied by Makrlík et al. ${ }^{8,9}$

Over the past two decades we have been investigating the well-established norbornadiene-quadricyclane system regarding the feasibility of active ion transport through artificial lipophilic membranes. ${ }^{10-13}$ The light induced $[2+2]$-cycloaddition or cycloreversion results in a change of the size of the ligand's cavity, which subsequently affects the complexation properties for metal ions. We synthesized a wide variety of symetrically four-fold-substituted norbornadiene and quadricyclane derivatives. Esters, polyethers as well as amides were considered as suitable binding domains mainly for alkali metal cations. ${ }^{14}$ The tetrakis(diisopropyl amide) substituted isomers $\mathbf{1}$ and $\mathbf{2}$ proved to be the most promising candidates in terms of active ion transport. ${ }^{15}$ The amides $\mathbf{1}$ and $\mathbf{2}$ showed remarkably differing association constants for $\mathrm{Li}^{+}, \mathrm{Na}^{+}$and $\mathrm{K}^{+}$and were successfully tested in passive transport experiments (Scheme 1).

\section{Alkaline earth ion complexation}

To widen the scope of the amide substituted norbornadienequadricyclane carriers, the complexation and passive transport properties of the amides $\mathbf{1}$ and $\mathbf{2}$ were studied using alkaline earth metals as central ions. To facilitate the understanding of the

Otto Diels-Institute for Organic Chemistry, Otto-Hahn-Platz 3-4,

24098 Kiel, Germany.E-mail: rherges@oc.uni-kiel.de;

Fax: + 49431 1558; Tel: +494311540

$\dagger$ Electronic supplementary information (ESI) available. See DOI: $10.1039 / \mathrm{c} 2 \mathrm{dt} 30242 \mathrm{j}$

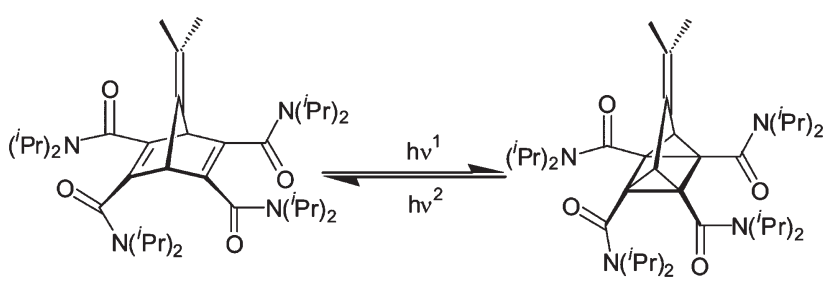

Scheme 1 The diisopropyl substituted norbornadiene 1 and the corresponding quadricyclane $\mathbf{2}$ are photoswitchable cation carriers.

complexation mechanism, the system was further investigated by DFT calculations.

\section{Results and discussion}

The substances $\mathbf{1}$ and $\mathbf{2}$ were synthesized according to our previously published procedure. ${ }^{15}$ To determine the extraction constants (see eqn (1) and (2)), we used CRAM's picrate extraction method using chloroform as the organic solvent. ${ }^{16,17}$

$$
\begin{gathered}
\mathrm{M}^{n+}{ }_{(\mathrm{aq})}+n \mathrm{~A}_{(\text {(aq })}^{-}+\mathrm{L}_{(\mathrm{org})} \rightleftarrows \mathrm{LMA}_{n(\mathrm{org})} \\
K_{\mathrm{ex}}=c\left(\mathrm{LMA}_{n}\right)_{\text {org }} c\left(\mathrm{M}^{n+}\right)_{\mathrm{aq}}{ }^{-1} c\left(\mathrm{~A}^{-}\right)_{\mathrm{aq}}{ }^{-n} c\left(\mathrm{~L}_{\text {org }}{ }^{-1}\right.
\end{gathered}
$$

The experimental results for both isomers are summarized in Table 1, assuming 1:1 stoichiometry and including the previously determined extraction constants for alkali metal cations.

Both carriers exhibit a remarkably high extraction constant with $\mathrm{Ba}^{2+}$. The fact that the extraction constant for $\mathrm{Ba}^{2+}$ is more than 20 times higher than for any other investigated alkaline earth and more than 300 times higher than for any alkali metal cation is particularly noteworthy. In comparison with numerous examples of ligands with high extraction constants for $\mathrm{Ba}^{2+}, 3,18-24$ the performance of the amides $\mathbf{1}$ and $\mathbf{2}$ is well above the average. A future application as $\mathrm{Ba}^{2+}$ selective receptors looks promising. In contrast, the selectivity between norbornadiene and quadricyclane reaches a maximum for $\mathrm{Mg}^{2+}$ and $\mathrm{Cs}^{+}$. A possible explanation for the outstanding extraction of $\mathrm{Ba}^{2+}$ 
Table 1 Extraction constants between water and chloroform of the diisopropyl amide substituted carriers with alkaline earth as well as alkali metal cations, ${ }^{15}$ assuming $1: 1$ stoichiometry

\begin{tabular}{lll}
\hline $\mathrm{Ion}^{a}$ & $K_{\text {ex }}(\mathbf{1})^{b}$ & $K_{\text {ex }}(\mathbf{2})^{b}$ \\
\hline $\mathrm{Mg}^{2+}$ & $18.8 \pm 2.1$ & $6.3 \pm 1.0$ \\
$\mathrm{Ca}^{2+}$ & $340.4 \pm 28.2$ & $149.8 \pm 10.5$ \\
$\mathrm{Sr}^{2+}$ & $308.7 \pm 26.9$ & $190.6 \pm 22.5$ \\
$\mathrm{Ba}^{2+}$ & $8566.5 \pm 405.2$ & $6142.1 \pm 572.7$ \\
$\mathrm{Li}^{+}$ & $14.1 \pm 0.4$ & $13.9 \pm 0.5$ \\
$\mathrm{Na}^{+}$ & $23.3 \pm 1.1$ & $8.6 \pm 0.3$ \\
$\mathrm{~K}^{+}$ & $6.2 \pm 0.2$ & $5.1 \pm 0.3$ \\
$\mathrm{Cs}^{+}$ & $18.5 \pm 0.5$ & $6.9 \pm 0.3$ \\
${ }^{a}$ The corresponding picrates were used. ${ }^{b}\left[\mathrm{~L}^{2} \mathrm{~mol}^{-2}\right]$. & \\
&
\end{tabular}

Table 2 Transport rates of the diisopropyl amide substituted norbornadiene $\mathbf{1}$ with alkaline earth ions

\begin{tabular}{llll}
\hline Ion & $J_{48}{ }^{a}$ & $J_{24 \mathrm{~A}}{ }^{a}$ & $J_{24 \mathrm{~B}}{ }^{a}$ \\
\hline $\mathrm{Mg}^{2+}$ & $1.33 \times 10^{-8}$ & $1.54 \times 10^{-8}$ & $1.12 \times 10^{-8}$ \\
$\mathrm{Ca}^{2+}$ & $1.44 \times 10^{-8}$ & $1.45 \times 10^{-8}$ & $1.43 \times 10^{-8}$ \\
$\mathrm{Sr}^{2+}$ & $1.53 \times 10^{-8}$ & $1.59 \times 10^{-8}$ & $1.47 \times 10^{-8}$ \\
$\mathrm{Ba}^{2+}$ & $2.24 \times 10^{-7}$ & $2.34 \times 10^{-7}$ & $2.14 \times 10^{-7}$
\end{tabular}

${ }^{a}$ All transport rates in $\mathrm{mol} \mathrm{m} \mathrm{m}^{-2} \mathrm{~s}^{-1}$.

could be the exclusive formation of a $2: 1$ complex due to the larger ionic radius. To clarify the binding situation, we carried out quantum chemical calculations.

\section{Transport rates}

The performance of the amides $\mathbf{1}$ and $\mathbf{2}$ in passive transport experiments was investigated using a supported liquid membrane setup as first described by Reinhoudt et $a l^{25}$ 2-Nitrophenyl octyl ether (NPOE) was used as the membrane phase with a microporous polypropylene foil as support.

The ion flow was continuously monitored by conductivity measurements in the acceptor phase over a period of $48 \mathrm{~h}$. The following Tables 2 and 3 show the averaged ion flow $J_{48}$ as well as the values averaged over the first and second half of the duration ( $J_{24 \mathrm{~A}}$ and $J_{24 \mathrm{~B}}$, respectively). Table 4 shows the ion flows obtained in blind experiments without any carrier in the membrane.

The results of the transport experiments are consistent with the extraction experiments. In all cases, the ion flows of the norbornadiene amide $\mathbf{1}$ are significantly higher than those of the corresponding quadricyclane 2 . As expected, the $\mathrm{Ba}^{2+}$ ion flow exceeds any other observed ion flow by a factor of about 10 . Beyond that, no significant decrease of the ion flows for $\mathrm{Ba}^{2+}$ and $\mathrm{Sr}^{2+}$ was observed during the experiments. Moreover, in accordance to the extraction constants, the selectivity towards $\mathrm{Ba}^{2+}$ between the norbornadiene $\mathbf{1}$ and the quadricyclane $\mathbf{2}$ is not very pronounced.

In contrast to the extraction experiments, no significant transport of $\mathrm{Mg}^{2+}$ and $\mathrm{Ca}^{2+}$ by the quadricyclane 2 could be detected. This fact gives rise to a comparatively high transport selectivity between isomers $\mathbf{1}$ and $\mathbf{2}$ for these two cations. The ion flow of
Table 3 Transport rates of the diisopropyl amide substituted quadricyclane 2 with alkaline earth ions

\begin{tabular}{llll}
\hline Ion & $J_{48}{ }^{a}$ & $J_{24 \mathrm{~A}}{ }^{a}$ & $J_{24 \mathrm{~B}}{ }^{a}$ \\
\hline $\mathrm{Mg}^{2+}$ & $5.11 \times 10^{-10}$ & $6.69 \times 10^{-10}$ & $3.53 \times 10^{-10}$ \\
$\mathrm{Ca}^{2+}$ & $1.14 \times 10^{-9}$ & $1.29 \times 10^{-9}$ & $9.81 \times 10^{-10}$ \\
$\mathrm{Sr}^{2+}$ & $5.56 \times 10^{-9}$ & $5.56 \times 10^{-9}$ & $5.56 \times 10^{-9}$ \\
$\mathrm{Ba}^{2+}$ & $5.43 \times 10^{-8}$ & $5.38 \times 10^{-8}$ & $5.47 \times 10^{-8}$ \\
${ }^{a}$ All transport rates in mol m${ }^{-2} \mathrm{~s}^{-1}$ & \\
\hline
\end{tabular}

Table 4 Transport rates of alkaline earth ions without any carrier

\begin{tabular}{llll}
\hline Ion & $J_{48 \mathrm{~h}}{ }^{a}$ & $J_{24 \mathrm{~A}}{ }^{a}$ & $J_{24 \mathrm{~B}}{ }^{a}$ \\
\hline $\mathrm{Mg}^{2+}$ & $1.33 \times 10^{-9}$ & $1.45 \times 10^{-9}$ & $1.21 \times 10^{-9}$ \\
$\mathrm{Ca}^{2+}$ & $9.33 \times 10^{-10}$ & $7.85 \times 10^{-10}$ & $1.08 \times 10^{-9}$ \\
$\mathrm{Sr}^{2+}$ & $4.33 \times 10^{-10}$ & $4.72 \times 10^{-10}$ & $3.93 \times 10^{-10}$ \\
$\mathrm{Ba}^{2+}$ & $5.93 \times 10^{-10}$ & $8.08 \times 10^{-10}$ & $3.77 \times 10^{-10}$ \\
${ }^{a}$ All transport rates in mol m${ }^{-2} \mathrm{~s}^{-1}$ & \\
\hline
\end{tabular}

$\mathrm{Mg}^{2+}$ with norbornadiene $\mathbf{1}$ is about 25 times higher than with quadricyclane $\mathbf{2}$, which could prove useful in possible future studies towards active ion transport.

\section{Quantum chemical calculations}

X-Ray crystal structures have shown that the norbornadiene amide 1 binds the central cation in a distorted quadratic pyramidal environment using the carbonyl oxygen atoms and the counterion as donors. ${ }^{15}$ To further elucidate the binding geometry, we conducted quantum chemical calculations of both $1: 1$ and $2: 1$ complexes on a DFT level of theory. The example structures of the $1: 1$ complexes of the norbornadiene amide 1 with $\mathrm{Mg}^{2+}$ and $\mathrm{Ba}^{2+}$ as well as the $2: 1$ complex with $\mathrm{Ba}^{2+}$ are shown in Fig. 1 . The comparison of the $1: 1$ complexes with $\mathrm{Mg}^{2+}$ and $\mathrm{Ba}^{2+}$ suggests the feasibility of a $2: 1$ complex with $\mathrm{Ba}^{2+}$, but not with $\mathrm{Mg}^{2+}$.

Geometry optimizations in vacuo were carried out to determine the binding situation of various cations in the cavity of the ion carriers $\mathbf{1}$ and $\mathbf{2}$. The calculation of complexation energies proved difficult as the solvation of both carrier and cation must not be neglected. Thus, we limited our focus on the differences in heat of formation for the investigated cations. For the $1: 1$ complexes, the distance of the central cation from the hypothetical plane defined by the four carbonyl oxygen atoms as well as the bond distances between the cation and the oxygen atoms were of particular interest. The results are shown in Table 5.

As expected, the distance of the central metal cation from the oxygen plane increases with the size of the cation. The central cation's distance from the oxygen plane in the quadricyclane $\mathbf{2}$ is always considerably larger than in the corresponding norbornadiene 1 while the bond lengths are almost identical. The increase in bond length corresponds with the growing metal cation radii. These observations imply a rigid carrier backbone with only little ability to adapt to the size of a complexated cation. Furthermore, the distance from the oxygen plane is always higher for 


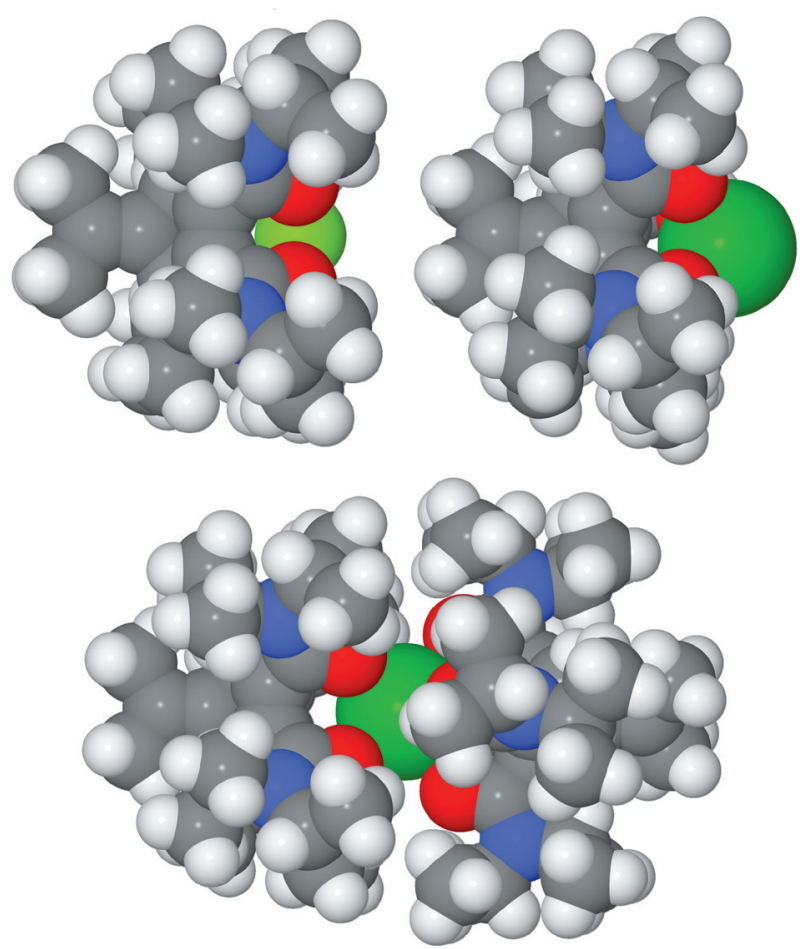

Fig. 1 Calculated geometries of the 1: 1 complex of norbornadiene 1 with $\mathrm{Mg}^{2+}$ (upper left side) and $\mathrm{Ba}^{2+}$ (upper right side) and the 2:1 complex of 1 with $\mathrm{Ba}^{2+}$ (bottom center).

Table 5 Distance between the plane defined by the four carbonyl oxygen atoms and the metal ion $\left(d_{\text {plane }}\right)$ and average bond length between oxygen and metal ion $\left(d_{\text {bond }}\right)$ for the calculated $1: 1$ complexes

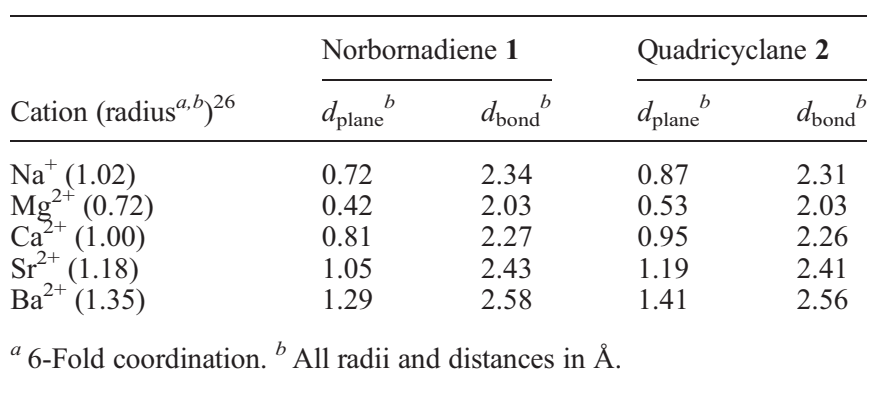

the quadricyclane $\mathbf{2}$, indicating a smaller cavity size which cannot accommodate the cation as well as the larger cavity of norbornadiene $\mathbf{1}$.

The calculation of the $2: 1$ complexes of the amide 1 resulted in stable minima only for $\mathrm{Ca}^{2+}, \mathrm{Sr}^{2+}$ and $\mathrm{Ba}^{2+}$. The binding of an additional ligand to the $1: 1 \mathrm{Sr}^{2+}$ complex is $1.94 \mathrm{kcal} \mathrm{mol}^{-1}$ less exothermic than for $\mathrm{Ba}^{2+}$. For $\mathrm{Ca}^{2+}$ the difference is even larger at $16.59 \mathrm{kcal} \mathrm{mol}^{-1}$. Considering hydration enthalpies decline with increasing cation radii, the difference in complex formation enthalpies will be even more pronounced in aqueous solution.

\section{Conclusions}

The tetrakis(diisopropyl amide) substituted norbornadiene and quadricyclane derivatives $\mathbf{1}$ and $\mathbf{2}$ proved to be outstandingly selective ligands towards $\mathrm{Ba}^{2+}$. The extraction constants between water and chloroform are more than 20 times higher for $\mathrm{Ba}^{2+}$ than for any other alkaline earth ion and more than 300 times higher than for any investigated alkali metal ion. The performance of the amides $\mathbf{1}$ and $\mathbf{2}$ in passive transport experiments was equally impressive, also showing high selectivity towards $\mathrm{Ba}^{2+}$. The results of the DFT calculations suggest that the formation of a $2: 1$ complex may be responsible.

\section{Experimental}

\section{Preparation of the solutions for the extraction experiments}

The picrate solutions needed for extraction were prepared by dissolution of dry picric acid in $0.01 \mathrm{M}$ alkaline earth metal hydroxide solutions. The $\mathrm{pH}$ value after complete dissolution of the picric acid was determined to be $\mathrm{pH} 7.0 \pm 0.1$. The $0.01 \mathrm{M}$ ligand solutions were prepared by dissolving the ligands in chloroform. Pure chloroform was used to perform the blank tests.

\section{General procedure for performing the extraction experiments}

For the extraction experiments $4 \mathrm{~mL}$ of each the ligand solution and the picrate solution were filled in a $10 \mathrm{~mL}$ screw-cap glass. The cap was closed and the glass was shaken for $2 \mathrm{~min}$ at room temperature using a Heidolph Reax 2000 shaking machine. For the determination of the association constant the experiment was repeated four times with identical samples and the mean value was formed. After separation of the phases the organic layer was sucked off with a pipette and filtered through glass wool. The filtrate was investigated using UV-Vis spectroscopy. The thickness of the quartz cell was $1 \mathrm{~cm}$. For the blank test an identical sample was prepared that contained deionized water instead of the picrate solution. The concentration of the picrate in the organic phase was calculated using Lambert-Beer's law.

\section{General procedure for performing the transport experiments}

The transport experiments were carried out at room temperature $\left(25^{\circ} \mathrm{C}\right)$ in a quartz apparatus with an exchange area of $8.5 \times 10^{-4} \mathrm{~m}^{2}$. The aqueous donor phase consisted of $23 \mathrm{~mL}$ of $0.15 \mathrm{M}$ alkaline earth nitrate solution while $23 \mathrm{~mL}$ HPLC grade water (Fluka) was used as the acceptor phase. Both phases were continuously stirred. A microporous Accurel® ${ }^{\circledR}$ PP membrane (Akzo Nobel, thickness: $92.5 \pm 17.5 \mu \mathrm{m}$ ) was used as support for the liquid membrane consisting of $15 \mathrm{mg}$ of the carrier in $285 \mathrm{mg}$ of NPOE. The conductivity in the acceptor phase was monitored using a WTW LF-340A conductometer equipped with a cell for pure water (type 325/01).

\section{Quantum chemical calculations}

Density functional theory calculations were carried out using the B3LYP/SDD method. ${ }^{27-29}$ All reported structures were verified as minima by frequency calculations. The Gaussian 09 software was used for all calculations. ${ }^{30}$ 


\section{Acknowledgements}

We gratefully acknowledge financial support for B.S. through DFG SFB 677 "Function by Switching”.

\section{References}

1 S. C. Lee, J. D. Lamb, M. Cai and J. T. Davis, J. Inclusion Phenom. Macrocyclic Chem., 2001, 40, 51.

2 Yu. M. Dedkov, N. V. Korsakova and V. A. Sychkova, J. Anal. Chem., 2006, 61, 1154.

3 C. Tu, K. Surowiec and R. A. Bartsch, Tetrahedron Lett., 2006, 47, 3443.

4 J. S. Kim, S. H. Lee, S. H. Yu, M. H. Cho, D. W. Kim, S. G. Kwon and E. H. Lee, Bull. Korean Chem. Soc., 2002, 23, 1085.

5 E. Makrlík and P. Vaňura, J. Radioanal. Nucl. Chem., 2006, 267, 699.

6 L. Mu, H. Huang, J. He, N. Zhang and J. Cheng, Chin. Sci. Bull., 2001, 46, 219.

7 M. J. Tapia, A. J. M. Valente, H. D. Burrows, V. Calderon, F. García and J. M. García, Eur. Polym. J., 2007, 43, 3838.

8 E. Makrlík, P. Vaňura and P. Selucky, J. Radioanal. Nucl. Chem., 2010, $\mathbf{2 8 3}, 615$ and cited literature.

9 E. Makrlík and P. Vaňura, Talanta, 1985, 32, 423.

10 R. Herges and W. Reif, Chem. Ber., 1994, 127, 1143.

11 R. Herges and W. Reif, Liebigs Ann., 1996, 761.

12 F. Starck, P. G. Jones and R. Herges, Eur. J. Org. Chem., 1998, 2533.

13 R. Herges, F. Starck, T. Winkler and M. Schmittel, Chem.-Eur. J., 1999, 5, 2965.

14 R. Herges and T. Winkler, Eur. J. Org. Chem., 2001, 4419.

15 T. Winkler, I. Dix, P. G. Jones and R. Herges, Angew. Chem., Int. Ed., 2003, 42, 3541.

16 J. M. Timko, S. S. Moore, D. M. Walba, P. C. Hiberty and D. J. Cram, J. Am. Chem. Soc., 1977, 99, 4207.

17 S. S. Moore, T. L. Tarnowski, M. Newcomb and D. J. Cram, J. Am. Chem. Soc., 1977, 99, 6398.

18 J. C. Moutet, E. Saint-Aman and I. Ion, J. Electroanal. Chem., 1996, 4, 187.
19 J. Petranek and O. Ryba, Tetrahedron Lett., 1977, 48, 4249.

20 B. W. Baldwin, T. Hirose, Z. H. Wang, T. Uchimaru and A. Yliniemelä, Chem. Lett., 1996, 415.

21 Y. H. Ma, R. Yuan, Y. Q. Chai and X. L. Liu, Anal. Bioanal. Chem., 2009, 395, 855.

22 O. M. Petrukhin, A. B. Kharitonov, Y. L. Urusov, E. V. Schipulo, N. Y. Kruchinina and V. E. Baulin, Anal. Chim. Acta, 1997, 353, 11.

23 T. Kleiner, F. Bongardt, F. Vögtle, M. W. Läubli, O. Dinten and W. Simon, Chem. Ber., 1985, 118, 1071.

24 R. Bissig, E. Pretsch, W. E. Morf and W. Simon, Helv. Chim. Acta, 1978, 61, 1520.

25 T. B. Stolwijk, E. J. R. Sudhölter and D. N. Reinhoudt, J. Am. Chem. Soc., 1987, 109, 7042.

26 CRC Handbook of Chemistry and Physics, ed. D. R. Lide, CRC Press, Boca Raton, London, New York, Washington, D.C., 80th edn, 1999, pp. 12-14.

27 P. J. Stephens, F. J. Devlin, C. F. Chabalowski and M. J. Frisch, J. Phys. Chem., 1994, 98, 11623.

28 P. Fuentealba, L. v. Szentpaly, H. Preuss and H. Stoll, J. Phys. B: At. Mol. Phys., 1985, 18, 1287.

29 T. H. Dunning Jr. and P. J. Hay, in Modern Theoretical Chemistry, ed. H. F. Schaefer III, Plenum, New York, 1976, vol. 3, pp. 1-28.

30 M. J. Frisch, G. W. Trucks, H. B. Schlegel, G. E. Scuseria, M. A. Robb, J. R. Cheeseman, G. Scalmani, V. Barone, B. Mennucci, G. A. Petersson, H. Nakatsuji, M. Caricato, X. Li, H. P. Hratchian, A. F. Izmaylov, J. Bloino, G. Zheng, J. L. Sonnenberg, M. Hada, M. Ehara, K. Toyota, R. Fukuda, J. Hasegawa, M. Ishida, T. Nakajima, Y. Honda, O. Kitao, H. Nakai, T. Vreven, J. A. Montgomery, Jr., J. E. Peralta, F. Ogliaro, M. Bearpark, J. J. Heyd, E. Brothers, K. N. Kudin, V. N. Staroverov, R. Kobayashi, J. Normand, K. Raghavachari, A. Rendell, J. C. Burant, S. S. Iyengar, J. Tomasi, M. Cossi, N. Rega, J. M. Millam, M. Klene, J. E. Knox, J. B. Cross, V. Bakken, C. Adamo, J. Jaramillo, R. Gomperts, R. E. Stratmann, O. Yazyev, A. J. Austin, R. Cammi, C. Pomelli, J. W. Ochterski, R. L. Martin, K. Morokuma, V. G. Zakrzewski, G. A. Voth, P. Salvador, J. J. Dannenberg, S. Dapprich, A. D. Daniels, O. Farkas, J. B. Foresman, J. V. Ortiz, J. Cioslowski and D. J. Fox, GAUSSIAN 09 (Revision A.02), Gaussian, Inc., Wallingford, CT, 2009. 